\title{
Elephant grass response to amino-acid synthesis inhibitor herbicides
}

\author{
Alexandre Magno Brighenti ${ }^{1 *}$, Francisco José da Silva Ledo ${ }^{1}$, Juarez Campolina Machado ${ }^{1}$, Leonardo \\ Henrique Ferreira Calsavara ${ }^{2}$, and Yago Vieira Guerra Varotto ${ }^{3}$
}

${ }^{1}$ Embrapa Dairy Cattle, Rua Eugênio do Nascimento 610, Juiz de Fora, MG, 36038-330 Brazil
${ }^{2}$ Emater-MG, Rua Major Mendonça 106, Coronel Xavier Chaves, MG, 36330-000 Brazil
${ }^{3}$ Centro de Ensino Superior de Juiz de Fora, Rua Luz Interior 345, Juiz de Fora, MG, Brazil

*Corresponding author: alexandre.brighenti@embrapa.br

\begin{abstract}
Elephant grass (Pennisetum purpureum Schum.) fodder productivity and quality are directly affected by weed interference. The difficulty in controlling weed species is one of the major limitations to the production and use of elephant grass as a forage crop in dairy farming and biomass for energy production. In this study, field experiments were conducted in 2014 and 2015 at two locations in Minas Gerais State, Brazil, to evaluate the tolerance of elephant grass pasture to acetolactate synthase inhibitor herbicides. The experimental pastures were treated at $1 \times$ and $2 \times$ the normal field-use rates $\left(\mathrm{g}\right.$ ai ha ${ }^{-1}$ ) with metsulfuron-methyl (7.8 and 15.6), chlorimuron-ethyl (15 and 30), halosulfuron (112.5 and 225), ethoxysulfuron (150 and 300), and nicosulfuron (60 and 120). A nontreated control was also included. The results showed that metsulfuron-methyl, chlorimuron-ethyl, halosulfuron, and ethoxysulfuron caused mild injury symptoms on elephant grass plants, but did not reduce forage biomass production. Nicosulfuron caused considerable percentage injury to the plants, which varied from 53\% to $73 \%$ and from $65 \%$ to $83 \%$ for the lower and higher rates, respectively. Elephant grass was tolerant of metsulfuron-methyl, chlorimuron-ethyl, halosulfuron, and ethoxysulfuron. Therefore, these herbicides could potentially control weeds in elephant grass fields.
\end{abstract}

Keywords: Forages; Napier grass; Pennisetum purpureum; selectivity; tolerance.

Abbreviations: DAA_days after herbicide application; BRS_Brazil; ALS_acetolactate synthase; MAP_mono-ammonium phosphate; $1 \times \_$recommended rate on the label; $2 \times \_$double the recommended rate.

\section{Introduction}

Elephant grass (Pennisetum purpureum Schum.), also known as Napier grass, is a perennial grass that grows widely across tropical and subtropical regions, and is particularly suitable as a cattle feedstock (Schmelzer, 1997). It is primarily used as forage for livestock in the dairy industry (Aroeira et al., 2001), but it is also grown as a source of biofuel (Strezov et al., 2008; Soares et al., 2011) because of its rapid growth and high biomass production (Borges et al., 2016). Crops grown only for biomass production can be used to generate considerable amounts of renewable energy in tropical and subtropical regions because of the high solar energy availability, the large amounts of available arable land, and abundant water resources. One of the major limiting factors affecting the productivity, and hence the cultivation, of elephant grass in Brazil is weed interference. Its nutritional quality and fresh and dry weight yields are directly affected by weed interference (Silva et al., 2002). The management of weeds in newly established elephant grass fields is critical during the early growth stages (3-6 weeks after planting) (Silva et al., 2002; Brighenti et al., 2015). Typically, the crop is established during the hot rainy season (November until January) under conditions that favor the emergence and establishment of weed species, especially monocotyledonous species such as Brachiaria (Abreu et al., 2006).

Acetolactate synthase (ALS) inhibitor herbicides are effective for selective weed control when low application rates are used on growing crops such as rice, sugarcane, wheat, barley, and corn (Oliveira Júnior, 2011). Selectivity is attained in tolerant crops through the rapid metabolism of the active ingredients to inactive compounds, whereas in sensitive species, little or no herbicide breakdown activity can be detected. Susceptible plants exhibit symptoms such as chlorosis and/or purpling of the leaves, necrosis of the apical meristem, followed by the death of older tissues. The ALS family of herbicides is considered environmentally friendly and effective in controlling a broad spectrum of weed species, including sedges (Rodrigues and Almeida, 2011). The ALS herbicides currently registered for use in Brazil include metsulfuron-methyl, chlorimuron-ethyl, halosulfuron, ethoxysulfuron, and nicosulfuron (Rodrigues and Almeida, 2011). However, there has been a lack of research on weed management in elephant grass, and most studies consider this species to be a weed rather than a crop (Cutts et al., 2011; Grey et al., 2015). The objective of this study was to evaluate the tolerance of elephant grass pasture to certain ALS inhibitor herbicides in order to increase the options available for weed control in elephant grass fields.

\section{Results and Discussion}

\section{Crop toxicity ratings}

The herbicides metsulfuron-methyl and chlorimuron-ethyl, at both low and high doses, did not cause visual symptoms of injury to elephant grass plants in Experiment 1 (Table 1). Visual symptoms of injury caused by halosulfuron were 
Table 1. Percentage phytotoxicity effects on elephant grass plants at 10, 20, and 30 days after application of the herbicides. Coronel Pacheco, Minas Gerais State, Brazil (Experiment 1).

\begin{tabular}{lcccc}
\hline Treatment & $\begin{array}{c}\text { Dose } \\
\left(\mathrm{g} \mathrm{ha}^{-1}\right)\end{array}$ & 10 & Day & \\
\cline { 3 - 5 } & 7.8 & $0.0 \mathrm{D}$ & 20 & 30 \\
\hline Metsulfuron-methyl & 15.6 & $0.0 \mathrm{D}$ & $0.0 \mathrm{C}$ & $0.0 \mathrm{C}$ \\
Metsulfuron-methyl & 15 & $0.0 \mathrm{D}$ & $0.0 \mathrm{C}$ & $0.0 \mathrm{C}$ \\
Chlorimuron-ethyl & 30 & $0.0 \mathrm{D}$ & $0.0 \mathrm{C}$ & $0.0 \mathrm{C}$ \\
Chlorimuron-ethyl & 112.5 & $1.6 \mathrm{C}$ & $0.0 \mathrm{C}$ & $0.0 \mathrm{C}$ \\
Halosulfuron & 225 & $5.6 \mathrm{~B}$ & $0.0 \mathrm{C}$ & $0.0 \mathrm{C}$ \\
Halosulfuron & 60 & $6.3 \mathrm{~B}$ & $35.3 \mathrm{~B}$ & $0.0 \mathrm{C}$ \\
Nicosulfuron & 120 & $9.0 \mathrm{~A}$ & $47.6 \mathrm{~A}$ & $53.1 \mathrm{~B}$ \\
Nicosulfuron & - & $0.0 \mathrm{C}$ & $0.0 \mathrm{C}$ & $65.2 \mathrm{~A}$ \\
Control & & $1.67 \pm 0.09$ & $2.22 \pm 0.04$ & $0.0 \mathrm{C}$ \\
\hline Mean \pm Standard Deviation & & & $2.49 \pm 0.03$ \\
\hline
\end{tabular}

1 Mean values followed by different letters are significantly different according to the Scott-Knott test $(P \leq 0.05)$.

Table 2. Percentage phytotoxicity effects on elephant grass plants at 10, 20, and 30 days after application of the herbicides. Coronel Pacheco, Minas Gerais State, Brazil (Experiment 2).

\begin{tabular}{lcccc}
\hline Treatment & $\begin{array}{c}\text { Dose } \\
\left(\mathrm{g} \mathrm{ha}^{-1}\right)\end{array}$ & \multicolumn{3}{c}{ Day } \\
\cline { 2 - 5 } & 7.8 & $0.0 \mathrm{C}$ & 20 & 30 \\
\hline Metsulfuron-methyl & 15.6 & $0.0 \mathrm{C}$ & $0.0 \mathrm{C}$ & $0.0 \mathrm{C}$ \\
Metsulfuron-methyl & 15 & $0.0 \mathrm{C}$ & $0.0 \mathrm{C}$ & $0.0 \mathrm{C}$ \\
Chlorimuron-ethyl & 30 & $0.0 \mathrm{C}$ & $0.0 \mathrm{C}$ & $0.0 \mathrm{C}$ \\
Chlorimuron-ethyl & 112.5 & $0.0 \mathrm{C}$ & $0.0 \mathrm{C}$ & $0.0 \mathrm{C}$ \\
Halosulfuron & 225 & $0.0 \mathrm{C}$ & $0.0 \mathrm{C}$ & $0.0 \mathrm{C}$ \\
Halosulfuron & 150 & $0.0 \mathrm{C}$ & $0.0 \mathrm{C}$ & $0.0 \mathrm{C}$ \\
Ethoxysulfuron & 300 & $0.0 \mathrm{C}$ & $0.0 \mathrm{C}$ & $0.0 \mathrm{C}$ \\
Ethoxysulfuron & 60 & $5.3 \mathrm{~B}$ & $0.0 \mathrm{C}$ & $0.0 \mathrm{C}$ \\
Nicosulfuron & 120 & $8.3 \mathrm{~A}$ & $56.3 \mathrm{~B}$ & $62.2 \mathrm{~B}$ \\
Nicosulfuron & - & $0.0 \mathrm{C}$ & $0.0 \mathrm{C}$ & $74.4 \mathrm{~A}$ \\
Control & \multicolumn{5}{l}{$0.0 \mathrm{C}$} \\
\hline Mean \pm Standard Deviation & $1.32 \pm 0.04$ & $2.11 \pm 0.02$ & $2.33 \pm 0.02$ \\
\hline
\end{tabular}

Table 3. Percentage phytotoxicity effects on elephant grass plants at 7, 14, and 21 days after application of the herbicides. Coronel Xavier Chaves, Minas Gerais State, Brazil (Experiment 3).

\begin{tabular}{lcccc}
\hline Treatment & $\begin{array}{c}\text { Dose } \\
\left(\mathrm{g} \mathrm{ha}^{-1}\right)\end{array}$ & 7 & Day & 21 \\
\cline { 3 - 5 } Metsulfuron-methyl & 7.8 & $1.5 \mathrm{D}$ & 14 & $0.0 \mathrm{C}$ \\
Metsulfuron-methyl & 15.6 & $2.5 \mathrm{C}$ & $1.2 \mathrm{E}$ & $0.0 \mathrm{C}$ \\
Chlorimuron-ethyl & 15 & $1.2 \mathrm{D}$ & $0.0 \mathrm{~F}$ & $0.0 \mathrm{C}$ \\
Chlorimuron-ethyl & 30 & $2.0 \mathrm{C}$ & $1.2 \mathrm{E}$ & $0.0 \mathrm{C}$ \\
Halosulfuron & 112.5 & $0.0 \mathrm{E}$ & $0.0 \mathrm{~F}$ & $0.0 \mathrm{C}$ \\
Halosulfuron & 225 & $1.2 \mathrm{D}$ & $2.2 \mathrm{D}$ & $0.0 \mathrm{C}$ \\
Ethoxysulfuron & 150 & $1.2 \mathrm{D}$ & $2.2 \mathrm{D}$ & $0.0 \mathrm{C}$ \\
Ethoxysulfuron & 300 & $1.7 \mathrm{C}$ & $5.5 \mathrm{C}$ & $73.2 \mathrm{~B}$ \\
Nicosulfuron & 60 & $5.5 \mathrm{~B}$ & $24.0 \mathrm{~B}$ & $83.0 \mathrm{~A}$ \\
Nicosulfuron & 120 & $7.0 \mathrm{~A}$ & $31.0 \mathrm{~A}$ & $0.00 \mathrm{C}$ \\
Control & - & $0.0 \mathrm{E}$ & $0.0 \mathrm{~F}$ & $2.43 \pm 0.05$ \\
\hline Mean \pm Standard Deviation & \multicolumn{5}{l}{ - } & $1.69 \pm 0.92$ & $2.16 \pm 0.12$ &
\end{tabular}

${ }^{1}$ Mean values followed by different letters are significantly different according to the Scott-Knott test $(P \leq 0.05)$.

Table 4. SPAD index, fresh matter weight of the above ground-biomass (FMWA), and total fresh matter weight (TFMW) of elephant grass. Coronel Pacheco, Minas Gerais State, Brazil (Experiment 1).

\begin{tabular}{|c|c|c|c|c|}
\hline Treatment & $\begin{array}{c}\text { Dose } \\
\left(\mathrm{g} \mathrm{ha}^{-1}\right)\end{array}$ & SPAD index & $\begin{array}{l}\text { FMWA } \\
\left(\mathrm{g} \mathrm{pot}^{-1}\right)\end{array}$ & $\begin{array}{l}\text { TFMW } \\
\left(\mathrm{g} \mathrm{pot}^{-1}\right)\end{array}$ \\
\hline Metsulfuron-methyl & 7.8 & $18.7 \mathrm{~B}^{1}$ & $59.7 \mathrm{~A}$ & $244.1 \mathrm{~A}$ \\
\hline Metsulfuron-methyl & 15.6 & $17.8 \mathrm{~B}$ & $62.3 \mathrm{~A}$ & $249.0 \mathrm{~A}$ \\
\hline Chlorimuron-ethyl & 15 & $20.1 \mathrm{~B}$ & $96.4 \mathrm{~A}$ & $234.5 \mathrm{~A}$ \\
\hline Chlorimuron-ethyl & 30 & $21.0 \mathrm{~B}$ & $77.0 \mathrm{~A}$ & $209.5 \mathrm{~A}$ \\
\hline Halosulfuron & 112.5 & $20.8 \mathrm{~B}$ & $81.9 \mathrm{~A}$ & $297.3 \mathrm{~A}$ \\
\hline Halosulfuron & 225 & $18.4 \mathrm{~B}$ & $81.2 \mathrm{~A}$ & $182.2 \mathrm{~A}$ \\
\hline Nicosulfuron & 60 & $14.3 \mathrm{C}$ & $31.0 \mathrm{~B}$ & $80.7 \mathrm{~B}$ \\
\hline Nicosulfuron & 120 & $14.2 \mathrm{C}$ & $37.2 \mathrm{~B}$ & $107.4 \mathrm{~B}$ \\
\hline Control & - & $24.6 \mathrm{~A}$ & $63.2 \mathrm{~A}$ & $228.1 \mathrm{~A}$ \\
\hline Mean \pm Standard Deviation & & $18.9 \pm 1.6$ & $65.5 \pm 14.3$ & $192.5 \pm 69.5$ \\
\hline
\end{tabular}


Table 5. SPAD index, height, and fresh matter weight (FMW) of elephant grass after application of the herbicides. Coronel Pacheco, Minas Gerais State, Brazil (Experiment 2).

\begin{tabular}{lcccc}
\hline Treatment & $\begin{array}{c}\text { Dose } \\
\left(\mathrm{g} \mathrm{ha}^{-1}\right)\end{array}$ & SPAD index & $\begin{array}{c}\text { Height } \\
(\mathrm{cm})\end{array}$ & $\begin{array}{c}\text { FMW } \\
\left(\mathrm{kg} \mathrm{ha}^{-1}\right)\end{array}$ \\
\hline Metsulfuron-methyl & 7.8 & $46.9 \mathrm{~A}^{1}$ & $113.3 \mathrm{~A}$ & $51,600.0 \mathrm{~A}$ \\
Metsulfuron-methyl & 15.6 & $48.9 \mathrm{~A}$ & $108.3 \mathrm{~A}$ & $42,800.0 \mathrm{~A}$ \\
Chlorimuron-ethyl & 15 & $50.6 \mathrm{~A}$ & $121.6 \mathrm{~A}$ & $38,266.0 \mathrm{~A}$ \\
Chlorimuron-ethyl & 30 & $49.4 \mathrm{~A}$ & $120.0 \mathrm{~A}$ & $47,466.6 \mathrm{~A}$ \\
Halosulfuron & 112.5 & $49.4 \mathrm{~A}$ & $105.0 \mathrm{~A}$ & $52,800.0 \mathrm{~A}$ \\
Halosulfuron & 225 & $49.3 \mathrm{~A}$ & $106.0 \mathrm{~A}$ & $41,866.6 \mathrm{~A}$ \\
Ethoxysulfuron & 150 & $48.1 \mathrm{~A}$ & $118.3 \mathrm{~A}$ & $42,666.6 \mathrm{~A}$ \\
Ethoxysulfuron & 300 & $48.2 \mathrm{~A}$ & $107.0 \mathrm{~A}$ & $41,733.3 \mathrm{~A}$ \\
Nicosulfuron & 60 & $22.8 \mathrm{~B}$ & $91.6 \mathrm{~B}$ & $20,933.3 \mathrm{~B}$ \\
Nicosulfuron & 120 & $17.4 \mathrm{C}$ & $78.3 \mathrm{~B}$ & $20,800.0 \mathrm{~B}$ \\
Control & - & $53.4 \mathrm{~A}$ & $121.6 \mathrm{~A}$ & $52,133.3 \mathrm{~A}$ \\
\hline Mean \pm Standard Deviation & & $44.0 \pm 1.9$ & $108.0 \pm 10.2$ & $40,278.7 \pm 1,2689.4$ \\
\hline
\end{tabular}

${ }^{1}$ Mean values followed by different letters are significantly different according to the Scott-Knott test $(P \leq 0.05)$.

Table 6. SPAD index, fresh matter weight (FMW) and dry matter weight (DMW) of elephant grass at 14 and 21 days after application of the herbicides. Coronel Xavier Chaves, Minas Gerais State, Brazil (Experiment 3).

\begin{tabular}{|c|c|c|c|c|c|c|}
\hline \multirow[t]{2}{*}{ Treatment } & \multirow{2}{*}{$\begin{array}{c}\text { Dose } \\
\left(\mathrm{g} \mathrm{ha}^{-1}\right)\end{array}$} & \multicolumn{2}{|c|}{ SPAD index } & \multirow{2}{*}{$\begin{array}{l}\text { Height } \\
\text { (cm) }\end{array}$} & \multirow{2}{*}{$\begin{array}{c}\text { FMW } \\
\left(\mathrm{kg} \mathrm{ha}^{-1}\right)\end{array}$} & \multirow{2}{*}{$\begin{array}{c}\text { DMW } \\
\left(\mathrm{kg} \mathrm{ha}^{-1}\right)\end{array}$} \\
\hline & & 14 & 21 & & & \\
\hline Metsulfuron-methyl & 7.8 & $46.5 \mathrm{~A}^{1}$ & $43.3 \mathrm{~A}$ & $50.4 \mathrm{~B}$ & $60,241.9 \mathrm{~A}$ & $8,995.0 \mathrm{~A}$ \\
\hline Metsulfuron-methyl & 15.6 & $36.5 \mathrm{D}$ & $40.8 \mathrm{~A}$ & $46.7 \mathrm{C}$ & $56,629.4 \mathrm{~A}$ & $8,301.1 \mathrm{~A}$ \\
\hline Chlorimuron-ethyl & 15 & $45.5 \mathrm{~B}$ & $42.5 \mathrm{~A}$ & $48.0 \mathrm{C}$ & $49,640.7 \mathrm{~A}$ & $7,029.4 \mathrm{~A}$ \\
\hline Chlorimuron-ethyl & 30 & $38.9 \mathrm{C}$ & $45.6 \mathrm{~A}$ & $49.0 \mathrm{C}$ & $44,896.1 \mathrm{~A}$ & $6,466.4 \mathrm{~A}$ \\
\hline Halosulfuron & 112.5 & $47.6 \mathrm{~A}$ & $43.8 \mathrm{~A}$ & $49.6 \mathrm{C}$ & $55,241.2 \mathrm{~A}$ & $7,858.0 \mathrm{~A}$ \\
\hline Halosulfuron & 225 & $48.02 \mathrm{~A}$ & $42.5 \mathrm{~A}$ & $49.1 \mathrm{C}$ & $48,487.7 \mathrm{~A}$ & $6,903.4 \mathrm{~A}$ \\
\hline Ethoxysulfuron & 150 & $44.9 \mathrm{~B}$ & $42.5 \mathrm{~A}$ & $51.8 \mathrm{~B}$ & $54,175.7 \mathrm{~A}$ & $8,093.2 \mathrm{~A}$ \\
\hline Ethoxysulfuron & 300 & $35.8 \mathrm{D}$ & $34.4 \mathrm{~B}$ & $51.8 \mathrm{~B}$ & $51,466,0 \mathrm{~A}$ & 7,481.1 A \\
\hline Nicosulfuron & 60 & $20.4 \mathrm{E}$ & $21.2 \mathrm{C}$ & $20.4 \mathrm{D}$ & $8,724.5 \mathrm{~B}$ & $2,725.4 \mathrm{~B}$ \\
\hline Nicosulfuron & 120 & $16.7 \mathrm{~F}$ & $18.9 \mathrm{C}$ & $21.1 \mathrm{D}$ & $7,420.1 \mathrm{~B}$ & $2,373.5 \mathrm{~B}$ \\
\hline Control & - & $47.3 \mathrm{~A}$ & $45.2 \mathrm{~A}$ & $60.2 \mathrm{~A}$ & $49,946.4 \mathrm{~A}$ & 7,519.7 A \\
\hline $\begin{array}{l}\text { Mean } \pm \text { Standard } \\
\text { Deviation }\end{array}$ & & $38.9 \pm 1.6$ & $38.2 \pm 3.4$ & $45.3 \pm 2.0$ & $44,260.9 \pm 10,406.3$ & $6,704.2 \pm 1,103.2$ \\
\hline
\end{tabular}

detected only in the first evaluation at 10 DAA. The younger leaves showed slight chlorosis, which disappeared and was not seen in later evaluations. Corn plants have been observed to be tolerant to halosulfuron (Dubelman et al., 1997). This is because a metabolic pathway in corn can rapidly inactivate the halosulfuron molecule through hydroxylation of the pyrimidine ring followed by a rapid conjugation with glucose. The toxic effects caused by nicosulfuron on elephant grass were characterized by yellowing of the whorl, chlorosis on some of the leaves, shoot stunting, and malformed leaves. The injury values for the 60 and $120 \mathrm{~g} \mathrm{ha}^{-1}$ doses were $6.3 \%$ and $9 \%$, respectively, at 10 DAA (Table 1). Subsequently, the symptoms spread to the central part of the leaf blade as the leaves developed. They had intensified by 30 DAA, reaching $53.1 \%$ and $65.2 \%$ for the lower and higher doses, respectively. In Brazil, corn crops have shown mild symptoms of phytotoxicity to nicosulfuron, even at locally recommended doses (Cavalieri et al., 2008; Barroso et al., 2012). Different corn genotypes, when subjected to nicosulfuron doses of 50 and $60 \mathrm{~g} \mathrm{ha}^{-1}$, showed yellowing of the emerging leaves, but this disappeared over time (Barroso et al., 2012). Möro and Damião Filho (1999) described the external signs of phytotoxicity and the histological changes in the leaves of corn hybrids treated with nicosulfuron. The typical symptoms of phytotoxicity caused by an $80 \mathrm{~g} \mathrm{ha}^{-1}$ dose consisted of discoloration and wrinkling of the middle portion of the central leaf blade of the whorls that were undergoing expansion at the time of application. These symptoms were also significant at 7 DAA. In Experiment 2, with the exception of nicosulfuron, none of the herbicide treatments resulted in any visual injury to treated elephant grass plants (Table 2). Nicosulfuron caused visual symptoms of phytotoxicity in all three evaluations. The cultivar Pioneiro had the same symptoms as BRS Kurumi (Experiment 1). These were yellowing of the leaf blade and wrinkling of the leaf edges. The percentage phytotoxicity ranged from $5.3 \%$ to $8.3 \%$ at 10 DAA. There was an intensification of the symptoms at the last evaluation where the values reached $62.2 \%$ and $74.4 \%$ for the 60 and $120 \mathrm{~g} \mathrm{ha}^{-1}$ doses, respectively. The experiment conducted at Coronel Xavier Chaves produced results that were similar to those observed in the experiments conducted at Coronel Pacheco. With the exception of nicosulfuron, all the herbicide treatments showed mild symptoms of injury at 7 DAA, but these had disappeared at 21 DAA (Table 3). The injury symptoms caused by nicosulfuron were pronounced at the first evaluation and worsened over time. The injury level eventually reached $73.2 \%$ and $83 \%$ for the recommended dose and double dose, respectively. All the herbicides other than nicosulfuron controlled broadleaf weeds and had little activity against monocots, which may explain the lack of injury seen in elephant grass.

\section{Yield and yield attributes}

In Experiment 1, all the treatments reduced the SPAD index values compared to the control (Table 4). However, nicosulfuron resulted in lower values compared to the other 
herbicides and the production of new shoots and total shoot production declined in the elephant grass plants treated with nicosulfuron. The SPAD index values were 22.8 for the $60 \mathrm{~g}$ $\mathrm{ha}^{-1}$ dose and 17.4 for the double dose, which were two to three times lower than the control (53.4) (Experiment 2) (Table 5). The SPAD index values for the other treatments were not significantly different from those for the control. Both doses of nicosulfuron resulted in considerable reductions in the height of the plants (Table 5). The treatments showed an approximately $40 \%$ reduction in fresh matter production per hectare compared to the control. The other herbicides did not significantly affect plant height and fresh matter production (Table 5). In the experiment conducted at Coronel Xavier Chaves, the SPAD index values had not declined by 14 DAA for the lower dose of metsulfuron or for the two halosulfuron treatments (Table 6). However, all the other treatments produced values that were significantly different from the control. The SPAD indexes at 21 DAA, for all treatments other than the highest dose of ethoxysulfuron and the two doses of nicosulfuron, were similar to the control. There was no loss in quality and forage yield when metsulfuron was applied at $10 \mathrm{~g} \mathrm{ha}^{-1}$ to a pasture of Cynodon dactylon 'Tifton 85', which indicated that this herbicide did not affect Tifton 85 (Janak et al., 2015). Furthermore, the quality and fresh biomass yield of ryegrass (Lolium perenne) forage were not affected when metsulfuron was applied at $6 \mathrm{~g} \mathrm{ha}^{-1}$ (James et al., 1999).

All the herbicide treatments reduced plant heights compared to the control (Table 6). However, the effect was greater when the plants were treated with nicosulfuron, which reduced plant height by approximately $33 \%$ compared to the control.

Only the two nicosulfuron treatment doses significantly reduced the fresh and dry matter production values when compared to the control (Table 6).

\section{Materials and Methods}

\section{Experimental Conditions}

Experiment 1 was carried out on February 03, 2014 in containers at the Embrapa Experimental Field in Coronel Pacheco County, Minas Gerais State, Brazil (21 ${ }^{\circ} 33^{\prime} 10.26^{\prime \prime} \mathrm{S}$ and $43^{\circ} 15^{\prime} 56.38^{\prime \prime} \mathrm{W}$ ).

Experiment 2 was conducted under field conditions at the Embrapa Experimental Field in Coronel Pacheco County in March 2014. Chemical analyses of the soil samples $(0-20 \mathrm{~cm}$ depth) were as follows: $\mathrm{pH}\left(\mathrm{H}_{2} \mathrm{O}\right)=5.1, \mathrm{P}=5.4 \mathrm{mg} \mathrm{dm}^{-3}, \mathrm{~K}$ $=55 \mathrm{mg} \mathrm{dm}{ }^{-3}, \mathrm{Ca}^{2+}=1.9 \mathrm{cmol}_{\mathrm{c}} \mathrm{dm}^{-3}, \mathrm{Mg}^{2+}=0.8 \mathrm{cmol}_{\mathrm{c}} \mathrm{dm}^{-3}$, $\mathrm{Al}^{3+}=0.2 \mathrm{cmol}_{\mathrm{c}} \mathrm{dm}^{-3}, \mathrm{H}+\mathrm{Al}=3.8 \mathrm{cmol}_{\mathrm{c}} \mathrm{dm}^{-3}$, total cation exchange capacity $=6.64 \mathrm{cmol}_{\mathrm{c}} \mathrm{dm}^{-3}, \mathrm{~V}=43 \%$, and $\mathrm{C}$ organic $=1.94 \mathrm{dag} \mathrm{kg}^{-1}$.

Experiment 3 was also established under field conditions in Coronel Xavier Chaves, Minas Gerais State, Brazil $\left(21^{\circ} 00^{\prime}\right.$ $42.86^{\prime \prime} \mathrm{S}$ and $\left.44^{\circ} 12^{\prime} 44.23^{\prime \prime} \mathrm{W}\right)$ on May 21, 2015. The chemical analyses of the soil samples $(0-20 \mathrm{~cm}$ depth) were as follows: $\mathrm{pH}\left(\mathrm{H}_{2} \mathrm{O}\right)=5.5, \mathrm{P}=10.5 \mathrm{mg} \mathrm{dm}^{-3}, \mathrm{~K}=390 \mathrm{mg}$ $\mathrm{dm}^{-3}, \mathrm{Ca}^{2+}=1.8 \mathrm{cmol}_{\mathrm{c}} \mathrm{dm}^{-3}, \mathrm{Mg}^{2+}=1.3 \mathrm{cmol}_{\mathrm{c}} \mathrm{dm}^{-3}, \mathrm{Al}^{3+}=$ $0.0 \mathrm{cmol}_{\mathrm{c}} \mathrm{dm}^{-3}, \mathrm{H}+\mathrm{Al}=5.12 \mathrm{cmol}_{\mathrm{c}} \mathrm{dm}^{-3}$, total cation exchange capacity $=9.22 \mathrm{cmol}_{\mathrm{c}} \mathrm{dm}^{-3}, \mathrm{~V}=44 \%$, and $\mathrm{C}$ organic $=2.39 \mathrm{dag} \mathrm{kg}^{-1}$.

\section{Experimental design and plant materials}

A completely randomized design with four replications was used in all experiments. In Experiment 1, the elephant grass plants were treated using the following herbicides at $1 \times$ and
$2 \times$ the recommended field-use rates $\left(\mathrm{g}\right.$ ai ha $\left.{ }^{-1}\right)$ : metsulfuronmethyl (7.8 and 15.6), chlorimuron-ethyl (15 and 30), halosulfuron (112.5 and 225), and nicosulfuron (60 and 120). A non-treated control was also included. Containers of $5 \mathrm{~kg}$ capacity were filled with a substrate containing equal quantities of sand, manure, and soil. Elephant grass (cultivar BRS Kurumi) stem cuttings (20 cm long) were planted in containers that had been arranged on benches in a natural environment and were directly exposed to the sun. The herbicide doses were applied on February 28, 2014, when the plants were approximately $0.15 \mathrm{~m}$ tall. All herbicides were applied using a backpack sprayer (Herbicat Ltda, Catanduva, São Paulo State, Brazil) and $\mathrm{CO}_{2}$ pressurized $\left(2 \mathrm{kgf} \mathrm{cm}^{-2}\right)$ to deliver a volume equivalent to $145 \mathrm{~L} \mathrm{ha}^{-1}$. The sprayer boom (0.5 m length) consisted of two flat fan nozzles (Magnojet BD 110 02) spaced $0.5 \mathrm{~m}$ apart. The environmental conditions during herbicide spraying were temperature, $27^{\circ} \mathrm{C}$; relative humidity, $68 \%$; and wind speed, $2 \mathrm{~m} \mathrm{~s}^{-1}$.

The treatments applied in Experiment 2 were the same as those used in Experiment 1 plus the herbicide ethoxysulfuron at application rates of 150 and $300 \mathrm{~g}$ ai ha ${ }^{-1}$. The experiment was carried out in an area that originally contained elephant grass pasture (cultivar Pioneiro). Planting was undertaken with a row spacing of $1.0 \mathrm{~m}$. The area of each plot was $10 \mathrm{~m}^{2}$ $(2 \mathrm{~m} \times 5 \mathrm{~m})$ and the net area was $2.5 \mathrm{~m}^{2}(1.25 \mathrm{~m} \times 2 \mathrm{~m})$.

The plant height was standardized using a brush cutter tractor at 20 days before herbicide application. The cutting height of the grass was fixed at $10 \mathrm{~cm}$.

The treatments were applied on March 31, 2014, when the plants reached an approximate height of $30 \mathrm{~cm}$. The herbicide was applied using the same backpack sprayer described for Experiment 1 . The spray boom ( $1.5 \mathrm{~m}$ length) comprised four flat nozzles (Magnojet BD 110 02) spaced $0.5 \mathrm{~m}$ apart, which delivered a volume equivalent to $145 \mathrm{~L} \mathrm{ha}^{-1}$. The environmental conditions during spraying were wind speed, 2 $\mathrm{m} \mathrm{s}^{-1}$; temperature $26^{\circ} \mathrm{C}$; and relative humidity, $64 \%$.

The treatments applied at Coronel Xavier Chaves were the same as those described for Experiment 2. Two days before planting, the experimental area was plowed and barred. Then, $20 \mathrm{~cm}$ deep grooves were made with row spacing of $1.0 \mathrm{~m}$. MAP fertilizer was applied at $200 \mathrm{~kg} \mathrm{ha}^{-1}$ during planting. BRS Kurumi cuttings, measuring $20 \mathrm{~cm}$ in length with four buds per cutting, were arranged in rows within the grooves and then covered with approximately $15 \mathrm{~cm}$ of soil. Each plot had four $2 \mathrm{~m}$ long lines of elephant grass $\left(8 \mathrm{~m}^{2}\right.$ with a net area of $4 \mathrm{~m}^{2}$ ). The herbicide treatments were applied on July 7,2015 , when the plant height was $15 \mathrm{~cm}$. All herbicides were applied using the same procedures described for Experiment 2. The environmental conditions during spraying were temperature, $23^{\circ} \mathrm{C}$; relative humidity, $72 \%$; and wind speed, $2.5 \mathrm{~m} \mathrm{~s}^{-1}$.

\section{Variables measured and procedures}

In Experiments 1 and 2, the effects of the treatments on the elephant grass plants were measured at 10,20, and 30 DAA using a scale of $0 \%$ to $100 \%$ where zero corresponds to no symptoms of injury and $100 \%$ represents plant death (SPCPD, 1995). The SPAD index was evaluated at 15 DAA using a SPAD-502 chlorophyll meter (Konica Minolta, Tokyo, Japan). The plants were harvested in Experiment 1 at 35 DAA and the fresh matter weight of the above-ground biomass and total fresh matter (roots, shoots, and leaves) were recorded.

In Experiment 2, the plant height was measured using a graduated ruler at $45 \mathrm{DAA}$. At the same time, the plants were cut at the soil surface to obtain the above ground fresh plant 
matter in $1.0 \mathrm{~m}^{2}$. The plants were weighed on a graduated scale and the values were converted to $\mathrm{kg} \mathrm{ha}^{-1}$.

The percentage phytotoxicity was evaluated in Experiment 3 at 7, 14, and 21 DAA (SBCPD, 1995). The SPAD index was measured at 14 and 21 DAA using the method described above. Plant height was measured using a graduated ruler at 30 DAA. At the same time, the plants were cut at the soil surface in order to obtain the above ground plant mass in 1.0 $\mathrm{m}^{2}$. The plants were then placed in paper bags and dried to a constant weight in a forced-air ventilation oven at $65^{\circ} \mathrm{C}$. The dried plant matter weights were then recorded. Both the fresh and dry matter weights were converted to $\mathrm{kg} \mathrm{ha}^{-1}$.

\section{Statistical analysis}

The percentage phytotoxicity data were normalized by square root transformation $(x+1)$ so that analysis of variance tests could be performed. The data were subjected to analysis of variance, and the mean values were compared using the Scott-Knott test $(P \leq 0.05)$. All statistical analyses were performed using SAEG software (Ribeiro Júnior, 2001).

\section{Conclusion}

This study reports on the tolerance shown by elephant grass to various amino-acid synthesis inhibitor herbicides, and thus provides options for controlling broadleaf weeds and sedge species in elephant grass fields. Metsulfuron-methyl, chlorimuron-ethyl, halosulfuron, and ethoxysulfuron did not injure elephant grass and have the potential to control weeds in elephant grass pasture.

\section{Acknowledgments}

Financial support from Fundação de Amparo a Pesquisa do Estado de Minas Gerais (FAPEMIG) and the Conselho Nacional de Desenvolvimento Científico e Tecnológico $(\mathrm{CNPq})$ is gratefully acknowledged.

\section{References}

Abreu JG, Evangelista AR, Souza IF, Rocha GP, Soares LQ, Santarosa LC (2006) Glyphosate e nitrogênio no controle de Brachiaria decumbens STAPF em capineiras estabelecidas. Cienc Agrotecnol. 30:977-987.

Aroeira LJM, Lopes FCF, Soares JPG, Deresz F, Verneque RS, Arcuri PB, Matos LL (2001) Daily intake of lactating crossbred cows grazing elephant grass rotationally. Pesqui Agropecu Bras. 36:911-917.

Barroso ALL, Ferreira Filho WC, Menezes CCE, Dan HA, Dan LGM, Melo Filho LC (2012) Selectivity of nicosulfuron and atrazine on different corn hybrids. Comum Sci. 3:255-262.

Borges LS, Aquino FC, Evangelista AF (2016) Potencial do capim elefante para geração de bioenergia - revisão. Rev Eletrônica Nutr. 13:4518-4523.

Brighenti AM, Oliveira MF, Ledo FJS, Muller MD, Martins CE, Varotto YVG (2015) Períodos de interferência de plantas daninhas no cultivo do capim-elefante. CD ROM. In: Congresso Internacional do Leite. Porto Alegre, RS: Embrapa Gado de Leite.

Cavalieri SD, Oliveira Júnior RS, Constantin J, Biffe DF, Rios FA, Franchini LHM (2008) Tolerância de híbridos de milho ao nicosulfuron. Planta Daninha. 26:203-214.
Cutts GS, Webster TM, Grey TL, Vencill WK, Lee RD, Tubbs RS, Anderson WF (2011) Herbicide effect on Napier grass (Pennisetum purpureum) control. Weed Sci. 59:255262.

Dubelman AM, Solsten TR, Fujiwara H, Mehrsheikh A (1997) Metabolism of halosulfuron-methyl by corn and wheat. J Agr Food Chem. 45:2314-2321.

Grey TL, Webster TM, Li X, Anderson W, Cutts GS (2015) Evaluation of control of Napier grass (Pennisetum purpureum) with tillage and herbicides. Invasive Plant Sci Manage. 8:393-400.

James TK, Rahman A, Cornwell MJ (1999) Pasture tolerance to the herbicide metsulfuron-methyl. In: Proceedings of the $52^{\text {nd }}$ New Zealand Plant Protection Conference, Havelock North, New Zealand.

Janak TW, Baumann PA, Janak SE, Grichar WJ (2015) Use of selected herbicides and application methods for tolerance to Tifton 85 Bermuda grass [Cynodon dactilon (L.) Pers.]. Am J Exp Agric. 8:289-298.

Möro FV, Damião Filho CF (1999) Alterações morfoanatômicas das folhas de milho submetidas à aplicação de nicosulfuron. Planta Daninha. 17:331-337.

Oliveira Júnior RS (2011) Mecanismos de ação de herbicidas. Pages 141-192. In: Oliveira Júnior RS, Constantin J, Inoue MH. Biologia e manejo de plantas daninhas. Omnipax, Curitiba.

Ribeiro Júnior JI (2001) Análises estatísticas no SAEG. Editora UFV, Viçosa. 301 p.

Rodrigues BN, Almeida FS, Ed (2011) Guia de Herbicidas. 6th edn. Londrina, PR: Grafmarke. 697 p.

SBCPD (1995) Procedimentos para instalação e análise de experimentos com herbicidas. Sociedade Brasileira da Ciência das Plantas Daninhas. Londrina. 42 p.

Schmelzer GH (1997) Review of Pennisetum section Brevivalvula (Poaceae). Euphytica. 97:1-20.

Silva W, Vilela D, Pereira AV, Ferreira FA, Ferreira RP (2002) Redução da interferência de Brachiaria decumbens na formação de pastagem de Pennisetum purpureum através de herbicidas. Planta Daninha. 20:273-281.

Soares IB, Marques OM, Benachour M, Abreu CAM (2011) Ethanol production by enzymatic hydrolysis of elephant grass. J Life Sci. 5:157-161.

Strezov V, Evans TJ, Hayman C (2008) Thermal conversion of elephant grass (Pennisetum purpureum Schum) to biogas, bio-oil and charcoal. Bioresour Technol. 99:83948399. 